\title{
Trophic strategies of the invasive Twospot livebearer (Pseudoxiphophorus bimaculatus, Teleostei: Poeciliidae) in a gradient of environmental quality in a central Mexico
}

Correspondence: Juan Pablo Ramírez-Herrejón ramirezherrejon@gmail.com

Submitted July 30, 2019 Accepted March 6, 2020 by Paulo Pompeu Epub Jun 12, 2020

Online version ISSN 1982-0224 Print version ISSN 1679-6225

Neotrop. Ichthyol.

vol. 18, no. 2, Maringá 2020
${ }^{\oplus}$ Omar Carbajal-Becerra ${ }^{1^{*}}$, ${ }^{\oplus}$ Karla Judith Olvera-Rodríguez ${ }^{*},{ }^{\oplus} \mathrm{Gabriel}$ Mariscal de Souza ${ }^{1},{ }^{\oplus}$ Omar Yair Durán-Rodríguez ${ }^{1},{ }^{\oplus}$ Arely RamírezGarcía ${ }^{2}$ and ${ }^{\oplus}$ Juan Pablo Ramírez-Herrejón ${ }^{3}$

Pseudoxiphophorus bimaculatus is an invasive species widely spread throughout freshwater ecosystems in central Mexico, for that reason we described its trophic strategy into a gradient of environmental quality. We sampled individuals of P. bimaculatus at eight sites located in the Lerma-Chapala and Pánuco River Basins during dry season. These basins have been impacted by industrialization and urbanization processes, but are considered as water reserves in México. To evaluate the environmental quality of the river, we applied the Visual-based Habitat Assessment, the Index of Biological Integrity and the Family-level Biotic Index. We assessed the trophic guild, the diet width, the omnivory level, and the diet selectivity. We also explored the relation of trophic strategies with the habitat condition. We captured a total of 202 individuals of P. bimaculatus from 10 to 67 $\mathrm{mm}$ of SL, finding a total of 24 food items. The diet of P. bimaculatus was composed of terrestrial, aquatic insects and bony fish. Pseudoxiphophorus bimaculatus in some sites can feed on different trophic levels, in other it is a specialist and secondary consumer. We found that $P$. bimaculatus changes its diet according the alterations in the habitat structure, water quality, and biotic integrity. Moreover, this invasive species can endure changes in the trophic web and food availability.

Keywords: Biological Invasions, Exotic Species, Feeding Ecology, Freshwater Ecosystems, Poecílidos.

1 Laboratorio de Integridad Biótica, Facultad de Ciencias Naturales Campus Aeropuerto, Universidad Autónoma de Querétaro (UAO), Carretera a Chichimequillas S/N, Ejido Bolaños, 76140 Querétaro, QRO, Mexico. (OCB) obecerra.carbajal@gmail.com; (KOR) kolvera.rod@gmail.com; (GMS) gabo.mariscal@gmail.com; (ODR) omarduro@gmail.com.

2 Programa Institucional de Doctorado en Ciencias Biológicas, Universidad Michoacana de San Nicolás de Hidalgo. Santiago Tapia 403, Morelia, Michoacán 58000, Mexico. are.ly32@live.com.mx.

3 CONACYT-Universidad Autónoma de Querétaro, Facultad de Ciencias Naturales, Campus UAQ-Aeropuerto, Carretera a Chichimequillas S/N, Ejido Bolaños, 76140 Querétaro, QRO, Mexico. ramirezherrejon@gmail.com, (corresponding author). 
Pseudoxiphophorus bimaculatus es una especie invasora ampliamente propagada en los ecosistemas de agua dulce del centro de México, por eso se describe su estrategia trófica en un gradiente de calidad ambiental. Se muestrearon individuos de $P$. bimaculatus en ocho sitios localizados en las cuencas de los Ríos Lerma-Chapala y Pánuco durante la temporada de secas. Estas cuencas se han visto afectadas por los procesos de industrialización y urbanización, pero la Comisión Nacional del Agua las considera reservas de agua en México. Para evaluar las condiciones ambientales de las cuencas, aplicamos el Índice de Integridad Biótica basado y el Índice Biótico basado en Familias. Evaluamos el gremio trófico, la amplitud de la dieta y la selectividad de la dieta de P. bimaculatus en sitios con diferente calidad ambiental. Además, exploramos la relación de las estrategias tróficas con la condición del hábitat. Capturamos un total de 202 individuos de P. bimaculatus de 10 a $67 \mathrm{~mm}$ de LP, encontrando un total de 24 artículos alimenticios. La dieta de $P$. bimaculatus está compuesta de insectos terrestres y acuáticos y restos óseos de peces. Pseudoxiphophorus bimaculatus en algunos sitios puede alimentarse de diferentes niveles tróficos, en otros, es especialista y consumidor secundario. Encontramos que $P$. bimaculatus cambia su dieta acorde con alteraciones en la estructura del hábitat, la calidad del agua y la integridad biótica. Además, esta especie invasora puede tolerar cambios en la red trófica y la disponibilidad de alimento.

Palabras clave: Ecología Alimenticia, Ecosistemas de agua dulce, Especies Exóticas, Invasión Biológica, Poecilidos.

\section{INTRODUCTION}

The introduction of exotic fish species represents a threat for the persistence of native fish in global scale (Bruton, 1995; Vitule et al., 2019), and the benefits that they provide fail to compensate the damage caused on ecosystems biodiversity (Moyle, 1997; Vitule et al., 2019). In Mexico, exotic fish species represent one of the most severe and less controlled problems (Contreras-MacBeath et al., 2014). However, there is a minimum concern about the negative consequences caused by fish species introduction (Zambrano et al., 2006). The introduction and the population establishment of exotic fish species represent a biological pollution and it can have similar effect to the physical and chemical alteration on freshwater ecosystems (Lachner et al., 1970; Capps, Flecker, 2013). This phenomenon is widely documented with exotic and invasive species of commercial importance, such as the Common carp (Cyprinus carpio Linnaeus, 1758), the Nile tilapia (Oreochromis niloticus (Linnaeus, 1758)), the Largemouth black bass (Micropterus salmoides (Lacepède, 1802)) or the Amazon sailfin catfish (Pterygoplichthys sp.) (Contreras-MacBeath et al., 2014). In addition, their invasion negative effect is commonly related to the exclusion of native fish population by predation, aggressiveness and territorial behavior, or indirect effects such as sediment re-suspension and habitat destruction (Zambrano, Hinojosa, 1999; Canonico et al., 2005; Cortés, 2016). 
However, there are exotic and invasive species that their potential negative effects have been poorly studied in the Central Mexico, such as the fish species of the Poeciliidae family. These fishes have been introduced for dipteran larvae control, but they generally go unnoticed because they are introduced by the accidental way as stowaways during the fish stoking of commercial and sport fishing species, aquarium dumping or when they escape from fish farms (Contreras-MacBeath et al., 1998; Vitule et al., 2009; Vitule et al., 2014). They are usually raised in aquariums or fish farms and released in the aquatic ecosystems where they usually achieve the population establishment in a short period of time (Contreras-MacBeath et al., 1998; Magalhães, Jacobi, 2017). Moreover, exotic poeciliids can modify the ecological function of freshwater systems after their colonization and they can be vectors of exotic parasites and diseases (Holitzki et al., 2013; Tripathi, 2014).

In this sense, the Twospot livebearer Pseudoxiphophorus bimaculatus (Heckel, 1848) can achieve a high level of invasiveness because it is a viviparous fish with short reproductive cycles and high fecundity (Thibault, Schultz, 1978; ContrerasMacBeath et al., 2014; Ramírez-García et al., 2017). This species is native from Mexico to Nicaragua, and specifically in Mexico it has been recorded in the states of Veracruz, Campeche, Chiapas, Oaxaca, Quintana Roo, Tabasco and Yucatán (Miller, 2009).

The scarce studies of P. bimaculatus are focused in its reproductive biology (RamírezGarcía et al., 2017), population attributes (Gómez-Márquez et al., 1999) and feeding habits (Trujillo-Jiménez, Toledo, 2007), but they have been performed at local scale and in artificial aquatic systems. These studies have concluded that P. bimaculatus is considered an omnivore species that can feed mainly on aquatic and terrestrial insects, and rarely can consume fish eggs and fish larvae. However, there is a gap of information about their population's attributes and the feeding strategies (i.e. active or passive predator, opportunistic predator) in the locations where it has been introduced, or where it has spread. In addition, the relationship between its trophic strategy and the habitat characteristics are still unknown. It is highly possible that $P$. bimaculatus can cause multiple effects on native biota and ecosystem functioning including predation and competition (Azevedo-Santos et al., 2016).

For these reasons, the aim of the present study was (1) to describe the biotic and physical integrity at eight sites located in the Lerma-Chapala and Pánuco River Basin, (2) describe the trophic strategy of P. bimaculatus into a gradient of water quality, habitat quality and biotic integrity and (3) to report the expansion of the new distribution range. The purpose of this study was to evaluate if $P$. bimaculatus changes its diet according the biological and physical integrity of sites. We expected that fish this species can tolerate variations in the elements of the trophic web, food availability and environmental condition.

\section{MATERIAL AND METHODS}

Study area. Study area is located at the central region of Mexico within the LermaChapala River and Pánuco River Basins. Eight sampling sites were selected, four are located in the state of Guanajuato: El Xote (XOT) $\left(20^{\circ} 57^{\prime} 08.5\right.$ ”N, 100 47'42.7”W), 
Los Galvanes (GAL) (2103'40.4”N, 100 48'12.1”W), El Charco del Ingenio (CHI) $\left(20^{\circ} 55^{\prime} 10.48 ” \mathrm{~N}, 100^{\circ} 43^{\prime} 41.46^{\prime} \mathrm{W}\right)$ and Paso de Vaqueros (PVA) $\left(21^{\circ} 22^{\prime} 03.9^{\prime \prime} \mathrm{N}\right.$, $\left.100^{\circ} 23^{\prime} 31.7^{\prime \prime} \mathrm{W}\right)$, and four in the state of Querétaro: Presa del Carmen (PRC) $\left(20^{\circ} 48^{\prime} 33.3 ” \mathrm{~N}, 100^{\circ} 18^{\prime} 33.9^{\prime \prime} \mathrm{W}\right)$, El Oasis (OAS) (2059'54.5”N, 9942'11.3”W),

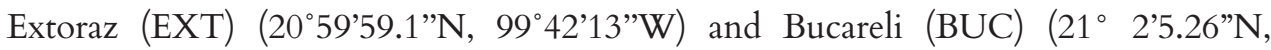
$99^{\circ} 37^{\prime} 0.86^{\prime \prime}$ W) (Fig. 1).

The gradient of environmental quality was obtained based on the results of habitat condition which was assessed using the Visual-based Habitat Assessment (VBHA) proposed by Barbour et al. (1999). The samplings sites show heterogeneity of habitat and land use (Tab. 1). The habitat heterogeneity and land use Field work was conducted during the dry season (from February to March 2014) because the chemical and physical parameters of water, the sediments and the cycles of organisms normalize once the streamflow decrease in speed and volume. Moreover, the anthropic degradation increases creating evident spatial variation along the river (MocayoEstrada et al., 2015).

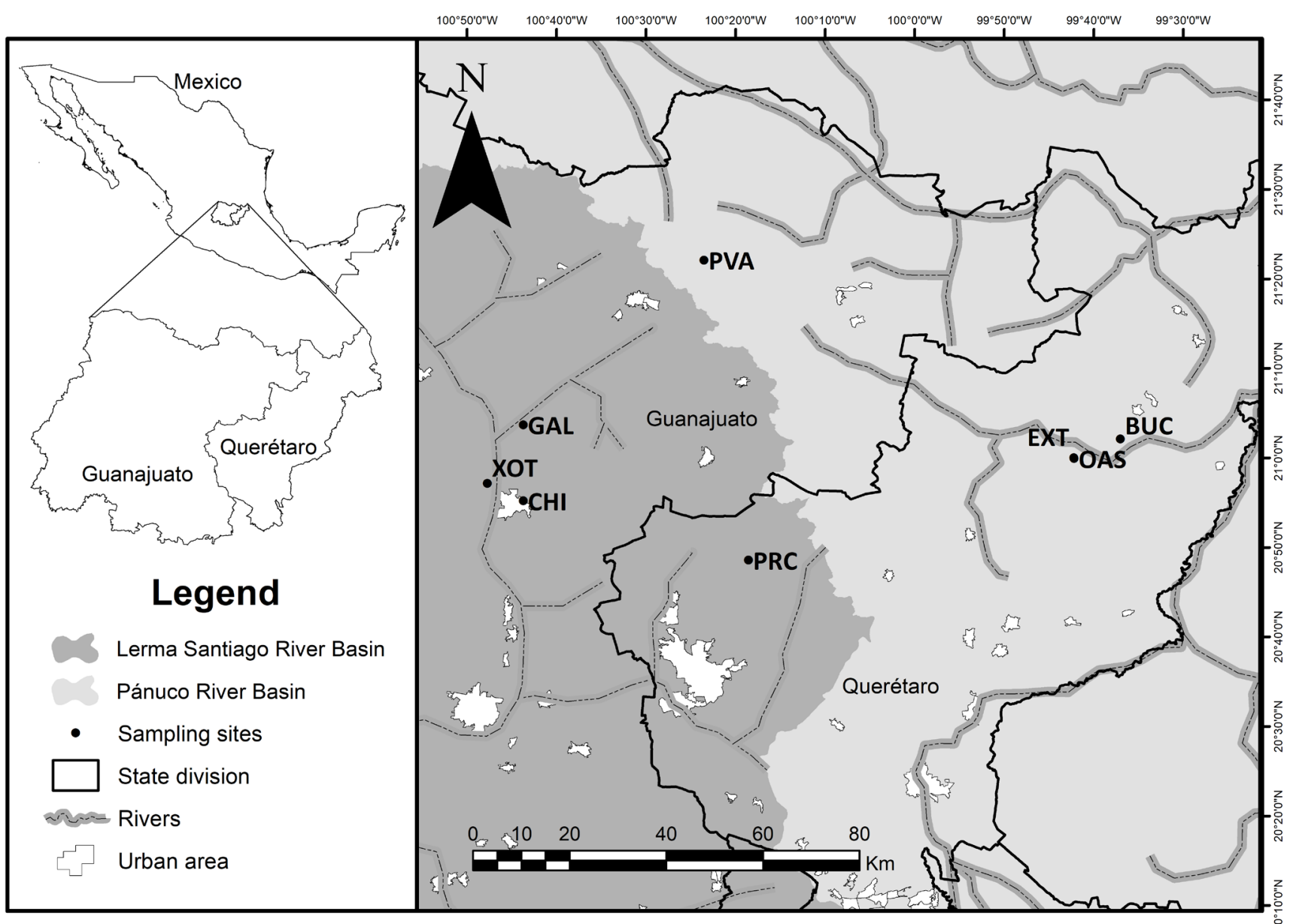

FIGURE 1 | Geographic location of study area and sampling sites located in the Lerma-Chapala River basin and Pánuco River basin in central Mexico. XOT = El Xote; CHI = El Charco del Ingenio; GAL = Los Galvanes; PRC = Presa del Carmen; PVA = Paso de Vaqueros; OAS = Oasis; EXT = Extoraz; BUC = Bucareli. 
TABLE 1 I Environmental heterogeneity gradient including basin, land use, shore line and Visual-based Habitat Assessment (VBHA), Index of Biological Integrity Based on Aquatic Macroinvertebrates Assemblages (IIBAMA) and Family-level Biotic Index (FBI) categories. For VHA: Poor =PO; Suboptimal =SO; and Optimal=OP. For IIBAMA: Poor=PO; and Regular=RE. For FBI: Fairly Poor=FP, and Fair=FA. For species: Native species=N; Exotic species=E; and Translocated species=T. XOT=El Xote; GAL=Los Galvanes; CHI= El Charco del Ingenio; PVA=Paso de Vaqueros; PRC= Presa del Carmen; OAS=El Oasis; EXT=Extoraz; BUC=Bucareli.

\begin{tabular}{|c|c|c|c|c|c|c|c|c|}
\hline $\begin{array}{l}\text { Sampling } \\
\text { sites }\end{array}$ & Basin & Environment & Shore line & Land use & VHA & IIBAMA & FBI & $\begin{array}{l}\text { Cohabitant } \\
\text { fish species }\end{array}$ \\
\hline XOT & Lerma-Chapala & Spring & $\begin{array}{l}\text { Modified by well construction to } \\
\text { retain water, walls and houses }\end{array}$ & Urban & $\mathrm{PO}$ & $\mathrm{PO}$ & FP & $1(\mathrm{~T})$ \\
\hline $\mathrm{CHI}$ & Lerma-Chapala & $\begin{array}{l}\text { High gradient } \\
\text { river }\end{array}$ & Unchanged, dam upstream & Reserve, Dam & OP & $\mathrm{PO}$ & $\mathrm{PO}$ & 1(N), 1(E), 1(T) \\
\hline GAL & Lerma-Chapala & $\begin{array}{l}\text { Low gradient } \\
\text { river }\end{array}$ & $\begin{array}{l}\text { Modified by the construction of } \\
\text { road crossing the river }\end{array}$ & Agricultural, Urban & $\mathrm{PO}$ & $\mathrm{PO}$ & FP & $3(\mathrm{~N}), 6(\mathrm{E}), 1(\mathrm{~T})$ \\
\hline PRC & Lerma-Chapala & $\begin{array}{l}\text { High gradient } \\
\text { river }\end{array}$ & $\begin{array}{l}\text { Modified by the construction } \\
\text { of roads and stone fences, also } \\
\text { deposition of sediments caused } \\
\text { by dredging }\end{array}$ & $\begin{array}{l}\text { Agricultural, } \\
\text { stables and free } \\
\text { grazing }\end{array}$ & $\mathrm{PO}$ & $\mathrm{PO}$ & FP & $1(\mathrm{~N}), 1(\mathrm{~T})$ \\
\hline PVA & Pánuco & $\begin{array}{l}\text { Low gradient } \\
\text { river }\end{array}$ & $\begin{array}{l}\text { Modified by the construction of } \\
\text { a bridge and road }\end{array}$ & Urban & $\mathrm{PO}$ & $\mathrm{PO}$ & GO & $1(\mathrm{~N}), 2(\mathrm{~T})$ \\
\hline OAS & Pánuco & $\begin{array}{l}\text { High gradient } \\
\text { stream }\end{array}$ & $\begin{array}{l}\text { Slightly modified by the } \\
\text { construction of roads, stone } \\
\text { fences and crops }\end{array}$ & Agricultural, Urban & MA & $\mathrm{PO}$ & $\mathrm{PO}$ & $1(N), 1(E)$ \\
\hline EXT & Pánuco & $\begin{array}{l}\text { High gradient } \\
\text { river }\end{array}$ & $\begin{array}{l}\text { Slightly modified by the } \\
\text { construction of roads }\end{array}$ & Agricultural, Urban & $\mathrm{PO}$ & PO & FA & $1(N), 1(E)$ \\
\hline BUC & Pánuco & $\begin{array}{l}\text { High gradient } \\
\text { river }\end{array}$ & $\begin{array}{l}\text { Slightly modified by the } \\
\text { construction of roads for } \\
\text { recreational activities and sand } \\
\text { extraction }\end{array}$ & $\begin{array}{l}\text { Agricultural, } \\
\text { Urban, Mining }\end{array}$ & MA & $\mathrm{RE}$ & GO & $3(N), 2(E)$ \\
\hline
\end{tabular}

\section{Data collection.}

Physical and biological integrity of sites. To evaluate the physical integrity, we measured the water physicochemical parameter and metric of habitat condition. To evaluate the biological integrity, we use two different biotic integrity indexes (Index of Biological Integrity and Family-level Biotic Index), widely used due their scientific accuracy and regional approach. Moreover, result can be obtained quickly, they are low cost and people without a proper scientific formation can calculate them (Pérez-Munguia et al., 2007).

Water physicochemical parameters. Potential of hydrogen $(\mathrm{pH})(\mathrm{pH}$ units), temperature $\left({ }^{\circ} \mathrm{C}\right)$, total dissolved solids (TDS) $(\mathrm{g} / \mathrm{L})$ and dissolved oxygen $(\mathrm{DO})(\mathrm{mg} / \mathrm{L})$ were measured using a multi-probe meter (Hydrolab Quanta).

Habitat condition. The channel morphology, bank structure, riparian vegetation, substrate heterogeneity, substrate embeddedness, sediment deposition and flow status were assessed by the VBHA.

Index of Biological Integrity. We used an Index of Biological Integrity Based on Aquatic Macroinvertebrates Assemblages (IIBAMA) proposed by Pérez-Munguia, Pineda-López (2005) and validate by Torres-Olvera et al. (2018), to access the biological 
integrity and categorize habitat condition as a response of the specific attributes of macroinvertebrates community assemblages. The variable to calculate IIBAMA were taxa richness; Ephemeroptera, Plecoptera and Trichoptera richness; sensitive insect richness; sensitive taxa richness; mean of tolerance values, and number of clingers taxa.

Family-level Biotic Index. We also estimated the Family-level Biotic Index (FBI) proposed by Hilsenhoff (1988) that categorizes water quality and organic pollution based on the tolerance values and abundance of families of arthropods.

The aquatic macroinvertebrates used in IIBAMA and FBI were sampled using a D-frame net $(300 \mathrm{~mm}$ width and $300 \mu \mathrm{m}$ mesh size) with a sample effort of 30 minutes per study site, including all the available habitat in a section of the river (five times the river width) as established in the NMX-AA-159-SCFI-2012 (Pineda-López et al., 2014). The aquatic macroinvertebrates were selected from detritus in situ and preserved in plastic vials within $80 \%$ ethanol. Specimens were identified at the taxonomic level of family using specialized keys (Bouchard, 2004; Merrit et al., 2008; Springer et al., 2010). The IIBAMA and FBI scores for Presa del Carmen (PRC), Oasis (OAS) and Extoraz (EXT) were obtained from Torres-Olvera et al. (2018).

Fish sampling. Fishes were collected during day (2-hour sampling effort per site) with a backpack electro-fisher (LR 20B Electrofisher, $600 \mathrm{~W}$ of maximum potential; 120 volts, $60 \mathrm{~Hz}, 20.8 \mathrm{amps}$ ) and hand nets (400 mm width and $5 \mathrm{~mm}$ mesh seize). Fishes were placed in ice water during 30 minutes and then each fish was injected into the abdominal cavity with 70\% ethanol. Samples were labeled and preserved in 70\% ethanol to further transport to the Biotic Integrity Laboratory at Autonomous University of Querétaro (UAQ). Specimens were identified following the criteria of Miller (2009). Standard length (SL) and weight were measured.

Gut analysis and trophic analysis. Accumulated prey diversity was measured, using Simpson's index to determine the minimum number of stomachs to characterize the feeding habits of P. bimaculatus (Magurran, 2004). The curve became asymptotic at 102 individuals for females, 56 individuals for males, by sites, 19 individuals in XOT, 32 individuals in PRC, 26 in PVA, 24 in OAS, and 22 in BUC. The curve did not become asymptotic in three study sites, in the CHI with 4 captured fishes, GAL with 7 captured fishes and $>34$ individuals in EXT.

Gut analysis was carried according to the quadrant method proposed by Hynes (1950). Feeding items were identified at the lowest taxonomic level possible. A modified version of the index of relative importance (IRI), proposed by Yáñez-Arancibia et al. (1976) was used: $R I I=(F * A) / 100$, where, $\mathrm{F}$ is the frequency of occurrence, and A is the area of collection, following the method proposed by Canto-Maza, VegaCendejas (2008) and applied by Ramírez-Herrejón et al. (2014). The IRI is expressed as percentages to describe the importance of each feeding item of the diet (Cortés, 1997). The IRI was also calculated by female and male and by gonadal maturity stage to explore a diet variation. The diet breadth $(\mathrm{Bi})$ was measured with the normalized Levin's index (Krebs, 1989), which is a measure of the diversity of ingested items, where $\mathrm{Bi}<0.60$ classified the fish as specialist and $\mathrm{Bi}>0.60$ as generalist fish. We used the omnivore index (OI) (Pauly et al., 1998) to describe the feeding behavior, which represents the variation of consumed prey's trophic levels. In addition, the food selectivity was assessed using the Ivlev's electivity index (Ivlev, 1961) which is expressed as: $E_{i}=\left(r_{i}-P_{i}\right) /\left(r_{i}+P_{i}\right)$ , where $r_{i}$ represents the relative abundance of prey consumed by the predator and $P_{i}$ 
is the relative abundance of prey in the ecosystem. The relative abundance of preys in each site was calculated using the data from the macroinvertebrates samples. Trophic level was calculated using TrophLab (Pauly et al., 1998) based on IRI values and the prey's trophic level.

Statistical analysis. We performed a principal component analysis (PCA) to identify the water physicochemical parameters most explanatory within the study sites. To explore the relation between P. bimaculatus diet and the habitat condition we performed a non-metric multidimensional scaling (NMDS) based on the Bray-Curtis similarity index, because it can afford datasets of species presence-absence (Bray, Curtis, 1957). The NMDS was made using the IRI values and the IIBAMA, FBI and VBHA values as habitat variables. Both analysis were performed with the statistical software PAST version 3.07 (Hammer et al., 2001).

\section{RESULTS}

Physicochemical parameters. The PVA site showed the lowest values of temperature $\left(13^{\circ} \mathrm{C}\right)$ and the highest value was in XOT and $\mathrm{CHI}$ sites $\left(28^{\circ} \mathrm{C}\right)$, the average value was $22.6 \pm 5.31{ }^{\circ} \mathrm{C}$. GAL site showed the lowest value of $\mathrm{pH}(4.5 \mathrm{pH})$, the highest was PVA site $(8.5 \mathrm{pH})$, average value of $\mathrm{pH}$ was $7.8 \pm 0.56$. The lowest value of TDS was in GAL $(0 \mathrm{ppm})$ and the highest in EXT site $(275 \mathrm{ppm})$, the average was $225.6 \pm 46.91(\mathrm{ppm})$. Site PRC presented the lowest value of OD $(2.5 \mathrm{mg} / \mathrm{L})$ and BUC site the highest $(10$ $\mathrm{mg} / \mathrm{L})$, average value was $5.5 \pm 2.46$ (mg/L) (Fig. 2).

Virtual-based Habitat Assessment (VBHA). The VBHA categorized the sites XOT, GAL, PRC, PVA and EXT as Poor given the low diversity of substrate available for epifauna, intermittent flow, high rates of sediment deposition (i.e. siltation), interruption of channel due to construction of roads and bridges, and unstable and eroded banks (Tab. 1). The sites HIG and BUC scored as Marginal given a poor heterogeneity of substrate, a significant rate of sediment deposition and the banks were moderately modified by roads increasing erosion areas. Finally, site CHI was categorized as Optimal because it had a higher diversity of substrate, low rates of sediment deposition, constant water flow, the banks had minimal rates of erosion and were covered by native vegetation. The human activities have minimally impacted.

Family-level Biotic Index (FBI). A total of 1991 macroinvertebrates were collected and distributed into seven classes, sixteen orders and forty-seven families (Tab. 2). Chironomidae was the most frequent family present in eight sites, followed by Coenagrionidae and Baetidae found in seven sites. The sampling sites with most taxa richness were BUC with thirty-two families and PVA with twenty-six families. The most abundant families were Chironomidae, Baetidae, Thiaridae and Physiidae.

Biological Integrity Based on Aquatic Macroinvertebrates Assembles (IIBAMA) scored sites XOT, CHI, GAL, PRC, PVA, OAS and EXT as Poor given a low taxa richness, a few or lack of EPT families and neither sensitive families (Tab. 1). The site BUC was Regular because of greater taxa richness, including EPT and sensitive 

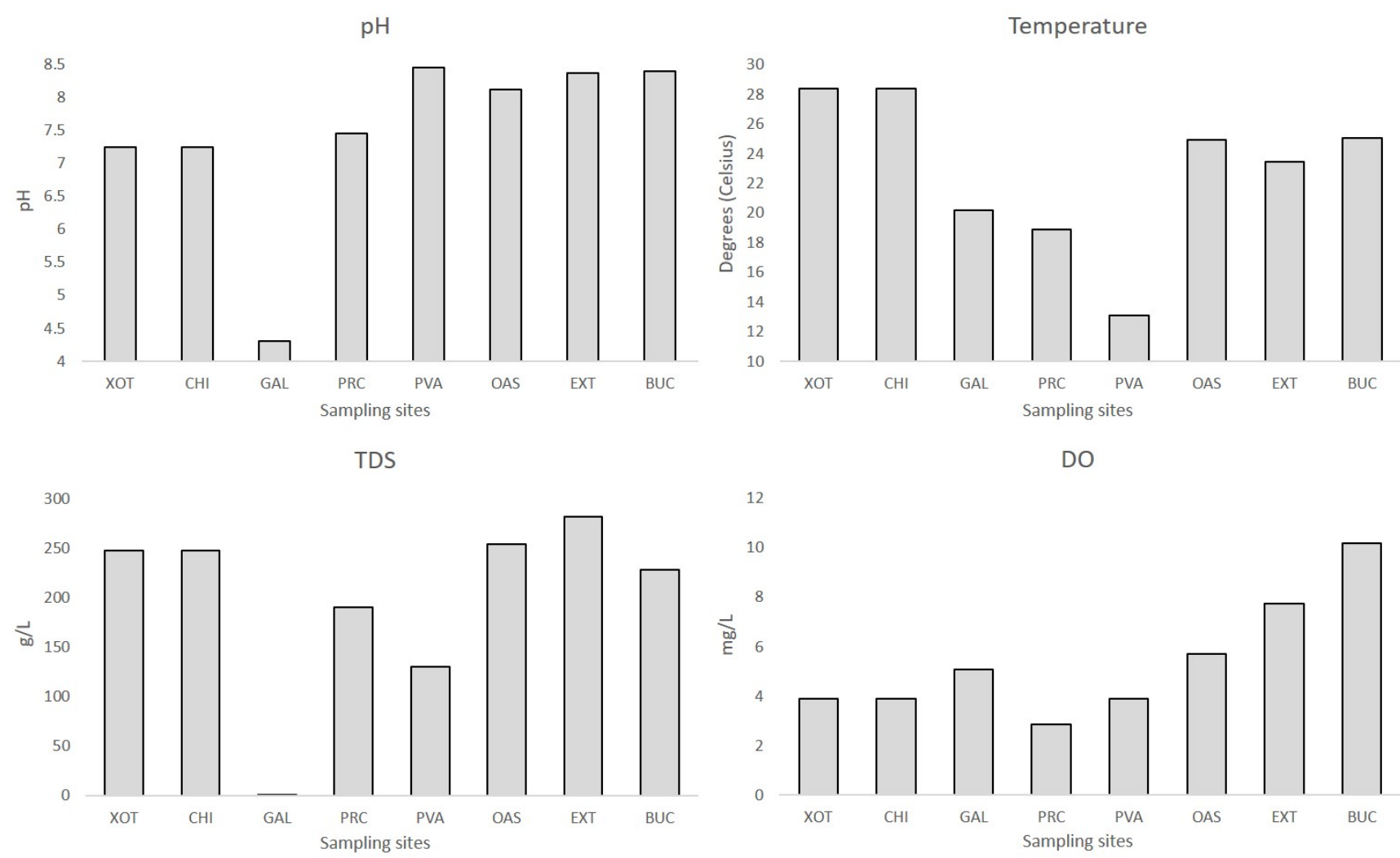

FIGURE 2 I Physicochemical parameters of water in each study site in central Mexico: temperature $\left({ }^{\circ} \mathrm{C}\right)$, TDS= Total dissolved solids $(\mathrm{g} / \mathrm{L})$ and DO= Dissolved oxygen $(\mathrm{mg} / \mathrm{L})$. XOT = El Xote; CHI = El Charco del Ingenio; GAL = Los Galvanes; PRC = Presa del Carmen; PVA = Paso de Vaqueros; OAS = Oasis; EXT = Extoraz; BUC = Bucareli.

families, and a greater number of clingers' taxa. Finally, the FBI categorized the sites $\mathrm{CHI}$ and OAS as Poor given a high abundance of tolerant families to organic pollution; XOT, GAL and PRC as Fairly poor and EXT as Fair because the higher abundance of individuals of families with low and high tolerance values; and PVA and BUC as Good given the higher abundance of families with low values of tolerance (Tab. 1).

Trophic analysis. We captured and analyzed a total of 202 individuals of $P$. bimaculatus from 10 to $67 \mathrm{~mm} \mathrm{SL}$, from 0.1 to $8.2 \mathrm{~g}$, finding a total of 24 food items and 31 empty guts. The diet of P. bimaculatus was mainly composed of terrestrial insects in PVA, HIG, EXT and BUC sites, and aquatic insects such as Corixidae in GAL site and Chironomidae in PRC site (Tab. 3). In XOT site the most important item was unidentified organic matter (UOM), while in CHI were fish eggs. The secondary elements in the diet were aquatic insects (Chironomidae and insect's detritus) in CHI, PVA and HIG; bony fish debris in XOT; terrestrial insects in GAL; plant debris in EXT; cladocerans in BUC, and UOM in PRC.

The males diet was mainly composed of terrestrial insects in PVA, HIG, EXT and BUC; UOM in XOT; fish eggs in CHI, and Chironomidae in PRC. In the same way, 
TABLE 2 I Taxonomic composition of macroinvertebrates collected in sampling sites. Numbers outside parenthesis are absolute abundance, numbers in parenthesis represent relative abundance (\%). XOT=El Xote; GAL=Los Galvanes; CHI= El Charco del Ingenio; PVA=Paso de Vaqueros; PRC= Presa del Carmen; OAS=El Oasis; EXT=Extoraz; BUC=Bucareli.

\begin{tabular}{|c|c|c|c|c|c|c|c|c|}
\hline Family & XOT & CHI & GAL & PRC & PVA & OAS & EXT & BUC \\
\hline Baetidae & & 3 (1.39) & $28(40)$ & $7(3.36)$ & $297(32.71)$ & $5(4.76)$ & $3(1.52)$ & $10(4.032)$ \\
\hline Leptohyphidae & & & & $1(0.48)$ & $193(21.26)$ & $10(9.52)$ & 34 (17.17) & 32 (12.9) \\
\hline Leptophlebiidae & & & & & $45(4.96)$ & & $7(3.54)$ & $4(1.613)$ \\
\hline Aeshnidae & & $1(0.46)$ & & $4(1.92)$ & & & & \\
\hline Caenidae & & 38 (17.59) & & & $18(1.98)$ & & & \\
\hline Calopterygidae & & & & & & $3(2.86)$ & $1(0.51)$ & $1(0.403)$ \\
\hline Coenagrionidae & & $12(5.56)$ & 12 (17.14) & $20(9.61)$ & $39(4.30)$ & $21(20)$ & $24(12.12)$ & $4(1.613)$ \\
\hline Gomphidae & & & & & $12(1.32)$ & $9(8.57)$ & $6(3.03)$ & $8(3.226)$ \\
\hline Lestidae & & $4(1.85)$ & & & $2(0.22)$ & & & \\
\hline Libellulidae & & & & $5(2.40)$ & $2(0.22)$ & $3(2.86)$ & $9(4.55)$ & $21(8.468)$ \\
\hline Perlidae & & & & & & & & $1(0.403)$ \\
\hline Belostomatidae & & & & $5(2.40)$ & $3(0.33)$ & & & $8(3.226)$ \\
\hline Corixidae & & & $22(31.43)$ & & $28(3.08)$ & & & \\
\hline Gelastocoridae & & & $1(1.43)$ & & & & & \\
\hline Gerridae & & & & & $12(1.32)$ & & & \\
\hline Hebridae & & & $1(1.43)$ & & & & $2(1.01)$ & \\
\hline Naucoridae & & & & & $2(0.22)$ & & $8(4.04)$ & $26(10.48)$ \\
\hline Nepidae & & & & $1(0.48)$ & & & & \\
\hline Notonectidae & & & $1(1.43)$ & & $1(0.11)$ & & & \\
\hline Veliidae & & & & $6(2.88)$ & $6(0.66)$ & & $3(1.52)$ & 48 (19.35) \\
\hline Corydalidae & & & & & & $3(2.86)$ & $7(3.54)$ & 22 (8.87) \\
\hline Hydrobiosidae & & & & & & & & $2(0.80)$ \\
\hline Hydropsychidae & & & & & & $1(0.95)$ & $1(0.51)$ & $18(7.25)$ \\
\hline Hydroptilidae & & & & & $1(0.11)$ & & & $1(0.40)$ \\
\hline Leptoceridae & & & & & & & & $1(0.40)$ \\
\hline Odontoceridae & & & & & $9(0.99)$ & & & \\
\hline Philopotamidae & & & & & & & $8(4.04)$ & $4(1.61)$ \\
\hline Dryopidae & & & & & $1(0.11)$ & & & \\
\hline Dytiscidae & & & $1(1.43)$ & & $9(0.99)$ & $2(1.90)$ & $1(0.51)$ & \\
\hline Elmidae & & & & & & $5(4.76)$ & $9(4.55)$ & $11(4.43)$ \\
\hline Haliplidae & & & & & $5(0.55)$ & & & \\
\hline Hydrophilidae & & & $2(2.86)$ & $2(0.96)$ & $49(5.40)$ & $2(1.90)$ & $3(1.52)$ & \\
\hline Staphylinidae & & & & & & & & $2(0.80)$ \\
\hline Ceratopogonidae & & $1(0.46)$ & & & $4(0.44)$ & $1(0.95)$ & & $1(0.40)$ \\
\hline Chaoboridae & & & & & & & $1(0.51)$ & \\
\hline Chironomidae & $1(5.56)$ & $44(20.37)$ & $1(1.43)$ & $128(61.54)$ & $142(15.64)$ & $23(21.90)$ & $23(11.62)$ & $8(3.22)$ \\
\hline Culicidae & & & & & $2(0.22)$ & & & \\
\hline Dixidae & & & & & $5(0.55)$ & & & \\
\hline Empididae & & & & & & & & $1(0.40)$ \\
\hline Ephydridae & & & & & $7(0.77)$ & & & \\
\hline Simuliidae & & & & $11(5.29)$ & & $1(0.95)$ & $2(1.01)$ & $11(4.43)$ \\
\hline Stratiomyidae & & $3(1.39)$ & & & & & $2(1.01)$ & $2(0.80)$ \\
\hline Cambaridae & & $28(12.96)$ & & & & & & \\
\hline Asellidae & & & $6(6.66)$ & & & & & \\
\hline Copepoda & & & 12 (13.33) & & & & & \\
\hline Mollusca & & & & $2(0.96)$ & & & & \\
\hline Physidae & $5(27.78)$ & 45 (20.83) & $1(1.43)$ & & & & $11(5.56)$ & $1(0.40)$ \\
\hline Thiaridae & $12(66.67)$ & & & & & $9(8.57)$ & $1(0.51)$ & \\
\hline Dugesiidae & & & & $14(6.73)$ & & & $32(16.16)$ & \\
\hline Hirudinea & & 37 (17.13) & & $2(0.96)$ & & & & \\
\hline Hydrachnidia & & & & & $14(1.54)$ & $7(6.67)$ & & \\
\hline Turbellaria & & & $2(2.22)$ & & & & & \\
\hline
\end{tabular}


the principal food items of the female's diet were terrestrial insects in XOT, PVA, EXT and BUC; Corixidae in GAL, and Chironomidae in CHI and PRC (Tab. 3).

The omnivore index indicated that P. bimaculatus is capable to feed on different trophic levels in XOT and CHI, but in independent study sites such as EXT, PRC and BUC $P$. bimaculatus fed on few trophic levels. Moreover, at two study sites, GAL and PVA, the fishes fed only on one trophic level (Tab. 4). The niche breadth index indicated that $P$. bimaculatus is generally specialist, and mainly secondary consumer, according with its trophic position in all sites except CHI, where it was catalogued as tertiary consumer (Tab. 4).

The electivity index described the preferred food items of P. bimaculatus. The sampling sites with the highest richness of food items were EXT (eight food items) and BUC (seven items), while the lowest was CHI (only two items) (Fig. 3). The most frequent food item was terrestrial insects, present in seven sites.

TABLE 3 I Relative importance index (\%IRI) for each food item of Pseudoxiphophorus bimaculatus in sampling sites for all individuals. Underlined numbers show the preferred food. UOM=Unidentified organic matter; TI=Terrestrial insects; $\mathrm{AID}=$ Aquatic insect's detritus; $\mathrm{n}=$ number of individuals collected; eg=empty guts; $\mathrm{Ei}=I$ vlev Index, ${ }^{\mathrm{a}} \mathrm{Ei}=1 ;{ }^{\mathrm{b}} \mathrm{Ei}=0.4 \pm 0.1 ;{ }^{\mathrm{c}} \mathrm{Ei}<0.1$. XOT=El Xote; GAL=Los Galvanes; $\mathrm{CHI}=\mathrm{El}$ Charco del Ingenio; PVA=Paso de Vaqueros; PRC= Presa del Carmen; OAS=El Oasis;

EXT=Extoraz; BUC=Bucareli.

\begin{tabular}{|c|c|c|c|c|c|c|c|c|}
\hline & $\begin{array}{c}\text { XOT } \\
n=22 \\
e g=2\end{array}$ & $\begin{array}{l}\text { CHI } \\
n=4\end{array}$ & $\begin{array}{c}\text { GAL } \\
\mathbf{n}=7\end{array}$ & $\begin{array}{l}\text { PRC } \\
n=35 \\
\text { eg=7 }\end{array}$ & $\begin{array}{l}\text { PVA } \\
n=35 \\
\text { eg=5 }\end{array}$ & $\begin{array}{c}\text { OAS } \\
n=34 \\
\text { eg=9 }\end{array}$ & $\begin{array}{l}\text { EXT } \\
n=34 \\
\text { eg }=6\end{array}$ & $\begin{array}{l}\text { BUC } \\
n=31 \\
e g=2\end{array}$ \\
\hline Plastic debris & & & & & & $1^{\mathrm{a}}$ & & \\
\hline Gravel & & & & & & & 1 & \\
\hline Plant debris & & & & & & $6^{\mathrm{a}}$ & & $1^{\mathrm{a}}$ \\
\hline UOM & $\underline{58} \underline{a}^{a}$ & & & $15^{\mathrm{a}}$ & & $1^{\mathrm{a}}$ & $8^{\mathrm{a}}$ & 12 \\
\hline Cladocera & & & & & & & $12^{\mathrm{a}}$ & $17^{\mathrm{a}}$ \\
\hline Bivalvia & & & & & & & & $1^{\mathrm{a}}$ \\
\hline Planorbidae & & & $1^{\mathrm{a}}$ & & & & & \\
\hline TI & $19^{\mathrm{a}}$ & & $39^{\mathrm{a}}$ & $14^{\mathrm{a}}$ & $\underline{96}^{\mathrm{a}}$ & $\underline{89^{a}}$ & $\underline{34}^{\mathrm{a}}$ & $\underline{59}^{\underline{a}}$ \\
\hline AID & & & & & $4^{\mathrm{a}}$ & $1^{\mathrm{a}}$ & $23^{\mathrm{a}}$ & \\
\hline Ephemeroptera & & & 4 & & & & & 1 \\
\hline Odonata larvae & & & & & & & 1 & 1 \\
\hline Coenagrionidae & & & 6 & & & & & \\
\hline Simulidae & & & $3^{\mathrm{a}}$ & & & & & \\
\hline Stratiomyidae & & 1.0 & & & & & & $1^{\mathrm{c}}$ \\
\hline Chironomidae & & 12.4 & & $\underline{66^{c}}$ & & & & \\
\hline Culicidae & $2^{\mathrm{a}}$ & & & $6^{\mathrm{a}}$ & & & & $2^{\mathrm{a}}$ \\
\hline Corixidae & & & $\underline{47}^{\underline{b}}$ & & & & & \\
\hline Notonoctidae & & $1^{a}$ & & & & & & \\
\hline Dytiscidae & & & & & & & $1^{\mathrm{b}}$ & \\
\hline Ostracoda & & & & & & & $5^{\mathrm{a}}$ & \\
\hline Physiidae & & & & & & $2^{\mathrm{a}}$ & $15^{b}$ & $4^{a}$ \\
\hline Cambarellus & & 1.8 & & & & & & \\
\hline Fish eggs & & $\underline{84}^{\mathrm{a}}$ & & & & & & \\
\hline Fish tissue & $21^{\mathrm{a}}$ & & & & & & & \\
\hline
\end{tabular}


Statistical analysis. The NMDS showed the ordination of the study sites in relation to food items and index scores along two-ordination axis (Fig. 4). The sites XOT, PRC and PVA corresponded to the high relative importance of UOM and Chironomidae, related with poor biological and physical condition. The isolated sites GAL (poor physical condition) and $\mathrm{CHI}$ (optimal physical condition) were ordinated due to the high relative importance of Corixidae and Fish eggs, respectively, both sites showed poor biological condition. The ordination of BUC and EXT indicated a high relative importance of aquatic insect detritus and cladocerans, associated with marginal physical condition and regular biological condition. The site OAS showed an intermediate ordination between the vectors of fish eggs and cladocerans in marginal physical condition.

TABLE 4 I Values of omnivory index (Values near to o indicates that the fish feed on few trophic levels, values near to 1 indicates that the fish feed on several trophic levels), Niche breadth (BA>0.60 denotes generalist fish, BA<0.6 denotes specialist fish) and Trophic level of Pseudoxiphophorus bimaculatus in all sampling sites. XOT=El Xote; GAL=Los Galvanes; $\mathrm{CHI}=$ El Charco del Ingenio; PVA=Paso de Vaqueros; PRC= Presa del Carmen; OAS=El Oasis; EXT=Extoraz; BUC=Bucareli.

\begin{tabular}{|r|c|c|c|c|c|c|c|c|c|} 
& XOT & CHI & GAL & PRC & PVA & OAS & EXT & BUC & TOTAL \\
\hline Omnivory index & 1.22 & 0.79 & 0 & 0.2 & 0 & 0.31 & 0.18 & 0.18 \\
Niche breadth & 0.47 & 0.1 & 0.32 & 0.37 & 0.08 & 0.05 & 0.45 & 0.16 \\
\hline Trophic level + SE & $2.78 \pm 0.41$ & $4.30 \pm 0.75$ & $3.2 \pm 0.4$ & $3.02 \pm 0.37$ & $3.2 \pm 0.4$ & $3.1 \pm 0.39$ & $3.14 \pm 0.39$ & $3.04 \pm 0.34$ & $3.2 \pm 0.43$ \\
\hline
\end{tabular}
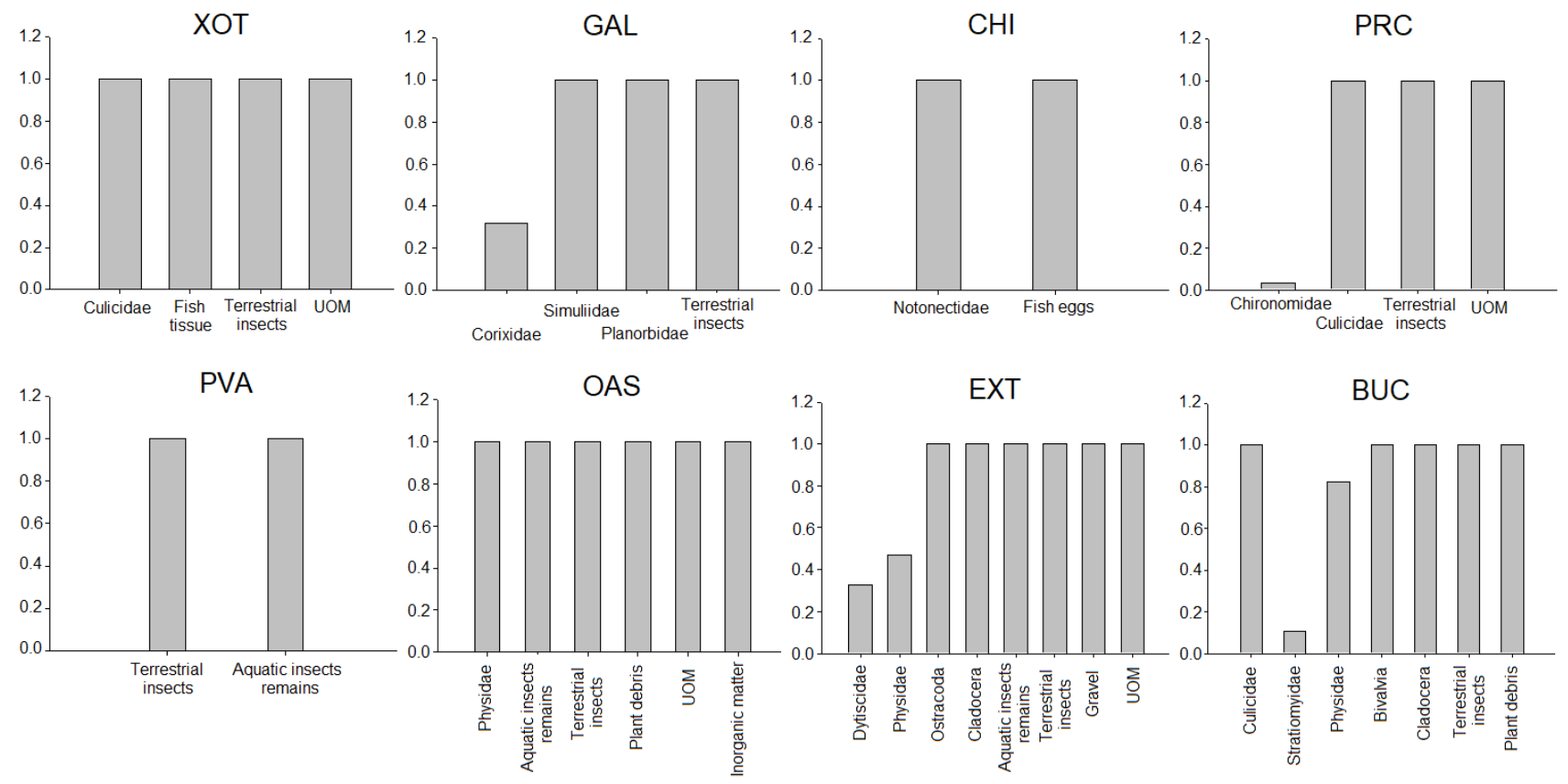

FIGURE 3 I Ivlev's Electivity index values for the food items of the diet of Pseudoxiphophorus bimaculatus in central Mexico. X axis=Prey electivity and Y axis=Prey taxa. XOT = El Xote; GAL = Los Galvanes; CHI = El Charco del Ingenio; PRC = Presa del Carmen; PVA = Paso de Vaqueros; OAS = Oasis; EXT = Extoraz; BUC = Bucareli. 


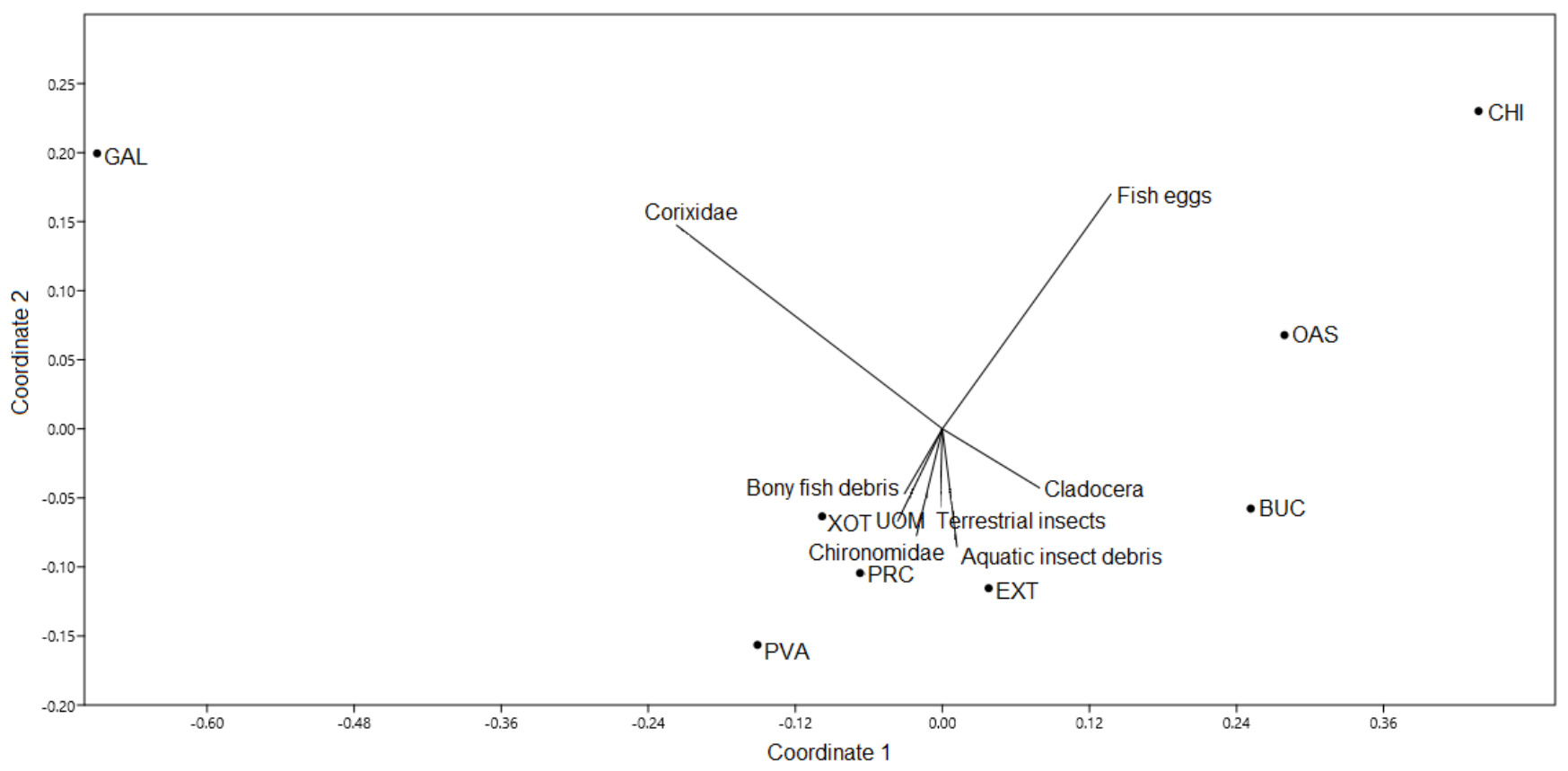

FIGURE 4 I Non-metric multidimensional scaling based on IRI scores of food items of the diet of Pseudoxiphophorus bimaculatus and the IIBAMA, FBI and VBHA scores of the study sites. Stress $=0$. Coordinate 1, $\mathrm{r}^{2}=0.9782$; Coordinate 2, $\mathrm{r}^{2}=0.2477 . \mathrm{XOT}=\mathrm{El} \mathrm{Xote}$; CHI $=\mathrm{El}$ Charco del Ingenio; GAL = Los Galvanes; PRC = Presa del Carmen; PVA = Paso de Vaqueros; OAS = Oasis; EXT = Extoraz; BUC = Bucareli.

\section{DISCUSSION}

The present study is the first to relate population's attributes and feeding components of an exotic and invasive species to the environmental quality through the three main axes of the freshwater ecosystems: physical, chemical and biological, performed in an environmental gradient within two river basins with different management strategies. This particular combination of biotic indexes, rapid bio-assessment protocols and trophic indexes is an integral approach that could be ideal to analyze biological invasions and the success of the potential invasion of the species.

We classified the study sites XOT, GAL and PRC as the most modified according to VHBA, IIBAMA and FBI scores. These sites are located in the highly degraded LermaChapala River Basin (Mercado-Silva et al., 2006). Changes in land use had modified the streams morphology and bank stability, with erosion increase as consequence. The high rates of sediment deposition had decreased the availability of substrate for epifauna, therefore the aquatic macroinvertebrates community in these sampling sites was configured mainly by burrowers, such as Chironomidae. The chironomids can live in conditions of pollution such as high turbidity and eutrophication by sewage (Rae, 1989), high temperatures, low dissolved oxygen, hard water and high contents of river sedimentation (Al-Shami et al., 2010; Lencioni et al., 2012). Other studies had mentioned that in aquatic degraded systems the food resources are poorly diverse, such as we found in our study (Ramírez-Herrejón et al., 2014). Pseudoxiphophorus bimaculatus is found in different sites with different biological and physical integrity. More specifically, it can endure changes in the elements of the trophic web and food 
availability. We found that this fish species was a carnivore-insectivore specialist and a secondary to third consumer according to the trophic levels. The species P. bimaculatus can feed of terrestrial insects, fish eggs and fish larvae, therefore it especially threatens native fish populations. This results coincided with Trujillo-Jimenez, Toledo (2007) who reported that this species was carnivore-insectivore and its main food resource were dipterans and hymenopterans, and that this poeciliid can prey on Largemouth black bass (M. salmoides) larvae.

The scores of trophic indexes in XOT showed that P. bimaculatus can feed from different trophic levels, while in GAL and PRC only from one level. In our three sites, $P$. bimaculatus was classified as specialist, carnivorous and secondary consumer. In the site GAL (Laja River basin) the relative abundance of P. bimaculatus was low ( $<10 \%)$. This site is characterized by not constant water flow, which has generated isolated pools, where this species co-inhabits with three native and seven exotic species, all mainly detritivore (Mariscal de Souza et al. pers. comm.). The sites PVA, OAS and EXT are located at the Pánuco River Basin, which has had several conservations efforts, unlike the LermaChapala River Basin. The streams morphology, the riparian vegetation and the erosion in these study sites are less modified by anthropic activities. These sites showed more habitat heterogeneity that supports the aquatic macroinvertebrates community with higher richness of tolerant and sensitive taxa, therefore food items were more diverse (Tews et al., 2004). This is similar in the artificial system (reservoir) "Los Carros" in the State of Morelos, Mexico, where this species have the function of predator (TrujilloJimenez, Toledo, 2007).

The site CHI is located at Lerma-Chapala River Basin, however it is placed in an ecological reserve where P. bimaculatus fed on more than one trophic level because we found fish eggs, crustaceans and aquatic insects into the gut, but it was considered as specialist because its diet was composed mainly of fish eggs $(>80 \%)$. In this site, the species was carnivorous and its trophic position was categorized as tertiary consumer. It is important highlight that, we found the native and oviparous fish species Notropis calientis in this same site, for this reason we can infer that P. bimaculatus can be a threat native fish species by egg predation. Escalera-Vazquez et al. (2016) mentioned that nonnative poeciliids fish species can influence the diet of the native species and to exclude it in freshwater environments.

The site BUC is located in the Biosphere Reserve of the Sierra Gorda in the State of Querétaro, which is an important tourist destination. The recreational activities had slightly impacted the habitat condition; however, the macroinvertebrates community is rich and abundant, which is an evidence of diversity of food items (Torres-Olvera et al., 2018). In this site, P. bimaculatus consumed three or more trophic levels and was catalogued as secondary consumer, specialist and carnivorous, but its diet was mainly composed by terrestrial insects. Our results showed that P. bimaculatus populations have the capacity to establish and to tolerate different environmental conditions. Its trophic strategy allows it to consume a wide variety of food resources, even if these are allochthonous, which provide it the ability to resist physical, chemical and biological variations on its habitat. This strategy confers to P. bimaculatus high degree of invasiveness with the potential to become the perfect invader (Magalhães, Jacobi, 2017). Therefore, to prevent the introduction, establishment and spread of exotic poeciliids, it is urgent to carry out campaigns to prevent fish introductions, to design management and conservation 
projects, eradication programs and habitat restoration activities. Some jurisdictions have introduced laws intended to regulate the collect, transport and released of many aquatic species around the globe into new habitats, but these regulations have rarely had the desired effects (Patoka et al., 2018). The current situation demands a profound behavioral shift towards better practices and policies, or these multiple high-impact activities will continue eroding freshwater fish biodiversity and impairing essential ecosystem services (Pelicice et al., 2017).

Our results support the hypothesis that $P$. bimaculatus is a nonnative species that can cause multiple effects on native biota and ecosystem functioning including predation, competition, bioturbation, and spread of pathogens (Azevedo-Santos et al., 2016). This poeciliid species can produced important environmental, economic, and social disturbances in freshwater ecosystems, and it is highly worrying because this fish is widely spread in the central region of Mexico, one of the most important regions for the conservation of fish, due to its high degree of endemism (Domínguez-Domínguez et al., 2008).

The establishment of $P$. bimaculatus populations have disrupted the freshwater environments, because being highly resistant, it is capable of influencing different trophic webs, including terrestrial ones, causing invasional meltdown that facilitates the spread and impact of other nonnative species (Azevedo-Santos et al., 2016; Braga et al., 2018).

However, it is still lacking evidence about the negative effect of invasive P. bimaculatus on native species in freshwater ecosystems. For this reason, it is imperative, to encourage scientific research focused on the effect of P. bimaculatus on native species and freshwater ecosystems. Even more when the invasion process could directly depend on whether the recipient community provides niche opportunities (Braga et al., 2018). The studies on feeding ecology of invasive fish allow to understand its natural history and its role in the trophic ecology of aquatic ecosystems, which is essential to provide a basis for conservation (Braga et al., 2012).

\section{ACKNOWLEDGMENTS}

We would like to thank all those who collaborated on the project "Temporal variation of the biotic integrity in the Lerma-Chapala and Pánuco River basins", financed by the postgraduate program Maestría en Gestión Integrada de Cuencas (MAGIC) and Fondo para el Fortalecimiento de la Investigación de la Universidad Autónoma de Queretaro (FOFI-UAQ-2013). We thank Dra. Miriam Guadalupe Bojorge García for technical support. JPRH thanks CONACYT for the facilities provided for the development of this investigation. We thank the staff of the National Commission of Natural Protected Areas (CONANP) who are in charge of the Sierra Gorda biosphere Reserve of Querétaro. 


\section{REFERENCES}

- Al-Shami SA, Rawi CSM, HassanAhmad A, Nor SAM. Distribution of Chironomidae (Insecta: Diptera) in polluted rivers of the Juru River basin, Penang, Malaysia. J Environ Sci. 2010; 22(11):1718-27. https://doi.org/10.1016/ S1001-0742(09)60311-9

- Azevedo-Santos VM, García-Ayala JR, Fearnside PM, Esteves FA, Pelicice FM, Laurance WF, Benine RC. Amazon aquatic biodiversity imperiled by oil spills. Biodivers Conserv. 2016; 25:283134. https://doi.org/10.1007/s10531-0161192-9

- Barbour MT, Gerritsen J, Snyder BD, Stribling JB. Rapid bioassessment protocols for use in streams and wadeable rivers: periphyton, benthic macroinvertebrates, and fish. Washington (DC): U.S. Environmental Protection Agency; Office of Water; 1999.

- Bouchard RW. Guide to aquatic invertebrates of the Upper Midwest: identification manual for students, citizen monitors, and aquatic resource professionals. Saint Paul: University of Minnesota; 2004.

- Braga RR, Bornatowski H, Vitule JRS. Feeding ecology of fishes: and overview of the worldwide publications. Rev Fish Biol Fish. 2012; 22:915-29. https://doi. org/10.1007/s11160-012-9273-7

- Braga RR, Gómez-Aparicio L, Heger T, Vitule JRS, Jeschke JM. Structure evidence for invasional meltdown: broad support but with biases and gaps. Biol Invasions. 2018; 20:923-36. https://doi.org/10.1007/ s10530-017-1582-2

- Bray JR, Curtis JT. An ordination of the upland forest communities of Southern Wisconsin. Ecol Monogr. 1957; 27(4):32549. https://doi.org/10.2307/1942268

- Bruton MN. Have fishes had their chips? The dilemma of threatened fishes. Environ Biol Fishes. 1995; 43:1-27. https://doi. org/10.1007/BF00001812

- Canonico GC, Arthington A, McCrary JK, Thieme ML. The effects of introduced tilapias on native biodiversity. Aquat Conserv. 2005; 15(5):463-83. https://doi. org/10.1002/aqc.699
- Canto-Maza WG, Vega-Cendejas ME. Hábitos alimenticios del pez Lagodon rhomboides (Perciformes: Sparidae) en la laguna costera de Chelem, Yucatán, México. Rev Biol Trop. 2008; 56(4):1837-46. https://doi.org/10.15517/rbt.v56i4.5763

- Capps KA, Flecker AS. Invasive aquarium fish transform ecosystem nutrient dynamics. Proc R Soc B. 2013; 280(1769): 20131520. https://doi.org/10.1098/ rspb.2013.1520

- Contreras-MacBeath T, Gaspar-Dillanes MT, Huidobro-Campos L, Mejía-Mojica H. Especies acuáticas invasoras en México. In: Mendoza R, Koleff P, coordinators. Ciudad de México: Comisión Nacional para el Conocimiento y Uso de la Biodiversidad; 2014. p.413-25.

- Contreras-MacBeath T, Mojica HM, Wilson RC. Negative impact on the aquatic ecosystems of the state of Morelos, Mexico from introduced aquarium and other commercial fish. Aquarium Sci Conserv. 1998; 2(2):67-78. https://doi. org/10.1023/A:1009676403693

- Cortés E. A critical review of methods of studying fish feeding based on analysis of stomach contents: application to elasmobranch fishes. Can J Fish Aquat Sci. 1997; 54(3):726-38. https://doi.org/10.1139/ f96-316

- Cortés YM. El pez diablo: una especie exótica invasora. Biocenosis. 2016; 23(2):16-19.

- Dominguez-Dominguez O, Zambrano L, Escalera-Vázquez LH, Pérez-Rodríguez R, Pérez-Ponce de León G. Changes in the distribution of goodeids (Osteichthyes: Cyprinodontiformes: Goodeidae) in river basin of central Mexico. Rev Mex Biodivers; 2008: 79(2):501-12.

- Escalera-Vázquez LH, DomínguezDomínguez O, Hinojosa-Garro D, Zambrano L. Changes in diet, growth and supervivorship of the native Tequila Splitfin Zoogoneticus tequila in cooccurrence with the non-native Shortfin Molly Poecilia mexicana. Fundam Appl Limnol. 2016; 188(4):341-51. https://doi. org/10.1127/fal/2016/0932 
- Gómez-Márquez JL, Guzmán-Santiago JL, Olvera-Soto A. Reproducción y crecimiento de Heterandria bimaculata (Cyprinodontiformes: Poeciliidae) en la Laguna “El Rodeo”, Morelos, México. Rev Biol Trop. 1999; 47(3):581-92.

- Hammer Ø, Harper DAT, Ryan PD. PAST: paleontological Statistics Software Package for Education and Data Analysis. Palaeontol Electronica. 2001; 4(1):1-9.

- Hilsenhoff WL. Rapid field assessment of organic pollution with a familylevel biotic index. J North Am Benthol Soc. 1988; 7(1):65-68. https://doi. org/10.2307/1467832

- Holitzki TM, MacKenzie RA, Wiegner TN, McDermid KJ. Differences in ecological structure, function, and native species abundance between native and invaded Hawaiian streams. Ecol Appl. 2013; 23(6):1367-83. https://doi.org/10.1890/120529.1

- Hynes HBN. The food of fresh-water sticklebacks (Gasterosteus aculeatus and Pygosteus pungitius), with a review of methods used in studies of the food of fishes. J Anim Ecol. 1950; 19(1):36-58. https://doi.org/10.2307/1570

- Ivlev VS. Experimental ecology of the feeding of fishes. New Haven: Yale University Press; 1961.

- Krebs C. Ecological methodology. New York: Harper and Row Publisher; 1989.

- Lachner EA, Robins CR, Courtenay WR. Exotic fishes and other aquatic organisms introduced into North America [Internet]. Smithson Contrib Zool.1970; (59):1-29. http://doi.org/10.5479/si.00810282.59

- Lencioni V, Marziali L, Rossaro B. Chironomids as bioindicators of environmental quality in mountain springs. Freshw Sci. 2012; 31(2):525-41. https://doi.org/10.1899/11-038.1

- Magalhães ALB, Jacobi CM. Colorful invasion in permissive Neotropical ecosystems: establishment of ornamental non-native poeciliids of the genera Poecilia/Xiphophorus (Cyprinodontiformes: Poeciliidae) and management alternatives. Neotrop Ichthyol. 2017; 15(1):e160094. https://doi. org/10.1590/1982-0224-20160094

- Magurran AE. Measuring Biological Diversity. Oxford: Blackwell Science Ltd; 2004.
- Mercado-Silva N, Lyons J, Díaz-Pardo E, Gutiérrez-Hernández A, OrnelasGarcía CP, Pedraza-Lara C, Zanden MJV. Longterm changes in the fish assemblage of the Laja River, Guanajuato, central Mexico. Aquat Conserv. 2006; 16(5):533-46. https://doi.org/10.1002/aqc.737

- Merrit RW, Cummins KW, Berg MB. An introduction to the aquatic insects of North. Iowa: Kendall Hunt Publishing Company; 2008.

- Miller RR. Peces dulceacuícolas de México. Tlalpan: Comisión Nacional para el Conocimiento y Uso de la Biodiversidad; 2009.

- Moncayo-Estrada R, Lyons J, RamírezHerrejón JP, Escalera-Gallardo C, Campos-Campos O. Status and trends in biotic integrity in a sub-tropical river drainage: analysis of the fish assemblage over a three decade period. River Res Appl. 2015; 31(7):808-24. https://doi.org/10.1002/ rra. 2774

- Moyle PB. The importance of an historical perspective: fish introductions. Fisheries. 1997; 22(10):14.

- Patoka J, Magalhães ALB, Kouba A, Faulkes Z, Jerikho R, Vitule JRS. Invasive aquatic pets: failed policies increase risks of harmful invasions. Biodivers Conserv. 2018; 27:3037-46. https://doi.org/10.1007/ s10531-018-1581-3

- Pauly D, Christensen V, Dalsgaard J, Froese R, Torres F. Fishing down marine food webs. Science. 1998; 279(5352):860-63. https://doi.org/10.1126/ science.279.5352.860

- Pelicice FM, Azevedo-Santos VM, Vitule JRS, Orsi ML, Lima Junior DP, Magalhães ALB, Pompeu PS, Petrere Junior M, Agostinho AA. Neotropical freshwater fished at stake. Fish Fish. 2017; 18(6):111933. https://doi.org/10.111/faf.12228

- Pérez-Munguia RM, Pineda-López RF. Diseño de un índice de integridad biótica, para ríos y arroyos del centro de México, usando las asociaciones de macroinvertebrados. Entomol Mex. 2005; 4:241-45. 
- Pérez-Munguia RM, Pineda-López RF, Medina-Nava M. Integridad biótica en ambientes acuáticos. In: Sánchez O, Herzing M, Peters E, Márquez R, Zambrano L, editors. Perspectivas sobre conservación de ecosistemas acuáticos en México. Ciudad de México: Secretaría de Medio Ambiente y Recursos Naturales; Instituto Nacional de Ecología; United States Fish \& Wildlife Service; Unidos para la Conservación A.C.; Escuela de Biologia de la Universidad Michocana de San Nicolás de Hidalgo; 2007. p.71-111.

- Pineda-López RF, Pérez-Munguia RM, Mathuriau C, Villalobos-Hiriart JL, Barba-Álvarez R, Bernal T, BarbaMacías E. Programa Nacional de Reservas de Agua: Protocolo de muestreo de macroinvertebrados en aguas continentales para la aplicación de la Norma de Caudal Ecológico (NMX-AA-159SCFI-2012). Monterrey: Comisión Nacional del Agua (CONAGUA); 2014.

- Rae JG. Chironomid Midges as indicators of organic pollution in the Scioto River Basin, Ohio. Ohio J Sci. 1989; 89(1):5-9. Available from: https://kb.osu.edu/ bitstream/handle/1811/23297/V089N1_005. pdf?sequence $=1$ \&isAllowed $=y$

- Ramírez-García A, Ramírez-Herrejón JP, Medina-Nava M, Hernández-Morales R, Domínguez-Domínguez O. Reproductive biology of the invasive species Pseudoxiphophorus bimaculatus and Poecilia sphenops in the Teuchitlán River, México. J Appl Ichthyol. 2017; 34(1):1-10. https://doi.org/10.1111/jai.13543

- Ramírez-Herrejón JP, Moncayo-Estrada R, Balart EF, Camacho LAG, Rodríguez BV, Villanueva RA et al. Trophic interrelations between introduced common carp, Cyprinus carpio (Actinopterygii: Cypriniformes: Cyprinidae), and fish community in a eutrophic shallow lake. Acta Ichthyol Piscat. 2014; 44(1):45-58. https://doi.org/10.3750/AIP2014.44.1.06

- Springer M, Ramírez A, Hanson P. Macroinvertebrados de agua dulce de Costa Rica I. Rev Biol Trop. 2010; 58(S4):151-198. https://doi.org/10.15517/rbt.v58i4

- Tews J, Brose U, Grimm V, Tielbörger K, Wichmann MC, Schwager M, Jeltsch F. Animal species diversity driven by habitat heterogeneity/diversity: the importance of keystone structures. J Biogeogr. 2004; 31(1):79-92. https://doi.org/10.1046/j.03050270.2003.00994x
- Thibault RE, Schultz RJ. Reproductive adaptations among viviparous fishes (Cyprinodontiformes: Poeciliidae). Evolution. 1978; 32(2):320-33. https://doi. org/10.2307/2407600

- Torres-Olvera MJ, Durán-Rodríguez OY, Torres-García U, Pineda-López R, Ramírez-Herrejón JP. Validation of an index of biological integrity based on aquatic macroinvertebrates assemblages in two subtropical basins of central Mexico. Lat Am J Aquat Res. 2018; 46(5):945-60. https://doi.org/10.3856/vol46issue5-fulltext-8

- Tripathi A. The invasive potential of parasitic monogenoids (platyhelminthes) via the aquarium fish trade: an appraisal with special reference to India. Rev Aquac. 2014; 6(3):147-61. https://doi.org/10.1111/ raq.12035

- Trujillo-Jiménez P, Toledo BH. Alimentación de los peces dulceacuícolas tropicales Heterandria bimaculata y Poecilia sphenops (Cyprinidontiformes: Poeciliidae). Revista de Biología Tropical. 2007; 55(2):603-15.

- Vitule JRS, Bornatowski H, Freire CA, Abilhoa V. Extralimital introductions of Salminus brasiliensis (Cuvier, 1816) (Teleostei, Characidae) for sport fishing purposes: a growing challenge for the conservation of biodiversity in neotropical aquatic ecosystems. BioInvasions Rec. 2014; 3(4):291-96. https://doi.org/10.3391/ bir.2014.3.4.11

- Vitule JRS, Freire CA, Simberloff D. Introduction of nonnative freshwater fish can certainly be bad. Fish Fish. 2009; 10(1):98-108. https://doi.org/10.1111/j.14672979.2008.00312.x

- Vitule JRS, Occhi TVT, Kang B, Matsuzaki SI, Bezerra LA, Daga VS, Faria L, Frehse FA, Walter F, Padial AA. Intra-country introductions unraveling global hotspots of alien fish species. Biodivers Conserv. 2019; 28:3037-43. https://doi.org/10.1007/s10531019-01815-7

- Yáñez-Arancibia A, Curiel-Gómez J, Yáñez VL. Prospección biológica y ecológica del bagre marino Galeichthys caerulescens (Günther) en el sistema lagunar costero de Guerrero, México (Pisces: Ariidae). An Cent Cienc Mar Limnol. 1976; 3(1):125-80. 
- Zambrano L, Hinojosa D. Direct and indirect effects of carp (Cyprinus carpio L.) on macrophyte and benthic communities in experimental shallow ponds in central Mexico. Hydrobiologia. 1999; 408-409:131-38. https://doi. org/10.1023/A:1017085129620
- Zambrano L, Martínez-Meyer E, Menezes $\mathrm{N}$, Peterson AT. Invasive potential of common carp (Cyprinus carpio) and Nile tilapia (Oreochromis niloticus) in American freshwater systems. Can J Fish Aquat Sci. 2006; 63(9):1903-10. https://doi.org/10.1139/ F06-088

\section{AUTHOR'S CONTRIBUTION}

Omar Carbajal-Becerra: Conceptualization, Data curation, Formal analysis, Investigation, Methodology, Software, Writing-original draft, Writing-review \& editing.

Karla J. Olvera-Rodríguez: Conceptualization, Data curation, Formal analysis, Investigation,

Methodology, Software, Writing-original draft, Writing-review \& editing.

Gabriel Mariscal-de-Souza: Data curation, Formal analysis, Investigation, Methodology, Software, Writing-original draft, Writing-review \& editing.

Omar Y. Durán-Rodríguez: Conceptualization, Data curation, Formal analysis, Funding acquisition, Investigation, Methodology, Project administration, Resources, Software, Supervision, Writing-original draft, Writing-review \& editing.

Arely Ramírez-García: Software, Supervision, Validation, Writing-original draft, Writing-review \& editing.

Juan P. Ramírez-Herrejón: Conceptualization, Data curation, Formal analysis, Investigation,

Methodology, Project administration, Resources, Software, Supervision, Validation, Visualization, Writingoriginal draft, Writing-review \& editing.

\section{ETHICAL STATEMENT}

The Universidad Autónoma de Querétaro has the collection license (QR00000159) granted by the Ministry of Agriculture, Livestock, Rural Development, Fisheries and Food (Secretaría de Agricultura, Ganadería,

\section{Neotropical Ichthyology}

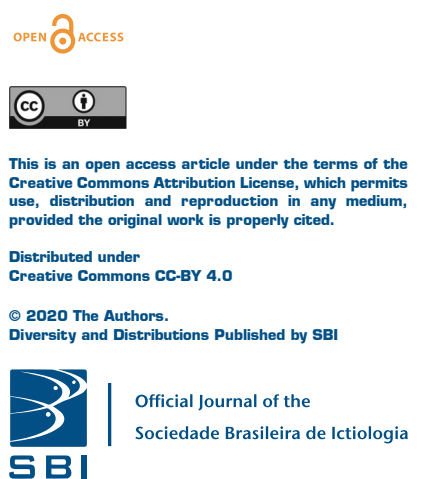

Desarrollo Rural, Pesca y Alimentación, SAGARPA) and the National Commission of Aquaculture and Fisheries (Comisión Nacional de Acuacultura y Pesca, CONAPESCA) of the Mexican government.

\section{COMPETING INTERESTS}

The authors declare no competing interests.

\section{HOW TO CITE THIS ARTICLE}

- Carbajal-Becerra O, Olvera-Rodríguez K, de Souza GM, Durán-Rodríguez OY, Ramírez-García A, Ramírez-Herrejón JP. Trophic strategies of the invasive Twospot livebearer (Pseudoxiphophorus bimaculatus, Teleostei: Poeciliidae) in a gradient of environmental quality in central Mexico. Neotrop Ichthyol. 2020; 18(2):e190080. https://doi. org/10.1590/1982-0224-2019-0080 